\title{
RU486 did not exacerbate cytokine release in mice challenged with LPS nor in $\mathrm{db} / \mathrm{db}$ mice
}

\author{
Baichun Yang*1, Ryan P Trump², Ying Shen1, Judi A McNulty', \\ Lisa G Clifton ${ }^{1}$, Stephen A Stimpson¹, Peiyuan Lin ${ }^{1}$ and Greg L Pahel ${ }^{1}$
}

\begin{abstract}
Address: ${ }^{1}$ Department of Metabolic Molecular Pharmacology, Research \& Development, GlaxoSmithKline, Research Triangle Park, USA and 2Department of Discovery Molecular Chemistry, Research \& Development, GlaxoSmithKline, Research Triangle Park, USA

Email: Baichun Yang* - Baichun.w.yang@gsk.com; Ryan P Trump - Ryan.P.Trump@gsk.com; Ying Shen - Ying.Y.Shen@gsk.com; Judi A McNulty - Judi.A.Mcnulty@gsk.com; Lisa G Clifton - Lisa.g.Clifton@gsk.com; Stephen A Stimpson - Stephen.A.Stimpson@gsk.com; Peiyuan Lin - Peiyuan.W.Lin@gsk.com; Greg L Pahel - gpahel@nc.rr.com

* Corresponding author
\end{abstract}

Published: 12 May 2008

BMC Pharmacology 2008, 8:7 doi:10.1|86/I47|-2210-8-7

This article is available from: http://www.biomedcentral.com/I47I-22/0/8/7

(C) 2008 Yang et al; licensee BioMed Central Ltd.

This is an Open Access article distributed under the terms of the Creative Commons Attribution License (http://creativecommons.org/licenses/by/2.0), which permits unrestricted use, distribution, and reproduction in any medium, provided the original work is properly cited.
Received: 20 November 2007

Accepted: 12 May 2008

\begin{abstract}
Background: Glucocorticoids down-regulate cytokine synthesis and suppress inflammatory responses. The glucocorticoid receptor (GR) antagonist RU486 may exacerbate the inflammatory response, and concerns over this exacerbation have limited the development and clinical use of GR antagonists in the treatment of diabetes and depression. We investigated the effects of RU486 on serum cytokines in $\mathrm{db} / \mathrm{db}$ mice and on lipopolysaccharide (LPS)-induced circulating TNF $\alpha$ levels in both normal AKR mice and diet-induced obese (DIO) C57BL/6 mice.

Results: Chronic treatment of db/db mice with RU486 dose-dependently decreased blood glucose, increased serum corticosterone and ACTH, but did not affect serum MCP-I and IL-6 levels. LPS dose-dependently increased serum TNF $\alpha$ in both AKR and C57BL/6 DIO mice, along with increased circulating corticosterone and ACTH. Pretreatment of the mice with RU486 dosedependently suppressed the LPS induced increases in serum TNF $\alpha$ and further increased serum corticosterone.
\end{abstract}

Conclusion: RU486 at doses that were efficacious in lowering blood glucose did not exacerbate cytokine release in these three mouse models. RU486 actually suppressed the lower dose LPSmediated TNF $\alpha$ release, possibly due to the increased release of glucocorticoids.

\section{Background}

Various clinical and pre-clinical investigations have indicated that antagonists of the glucocorticoid receptor (GR) could be useful in the treatment of diabetes $[1,2]$ and depression [3], but concerns about the effects of GR antagonists on the body's ability to regulate inflammatory responses [4] have hampered development of GR antagonists for these indications.
Activation of the GR with endogenous glucocorticoids (GCs) is the body's primary method for suppression of the inflammatory response [5]. In fact, host survival in bacterial and viral infection is dependent upon the proper control of the inflammatory response through timely activation of the hypothalamic-pituitary-adrenal (HPA) axis for the production of cortisol, the primary glucocorticoid in humans [6]. The innate immune system stimulates the controlled production and timely release of GCs to 
prevent an overly strong response to an ongoing localized inflammatory process [7]. Disruption of this response due to exhaustion of the adrenal cortex results in septic shock. In the treatment of septic shock, low doses of GCs have therapeutic effects by correcting adrenal cortex exhaustion, exerting appropriate anti-inflammatory properties, and enhancing endogenous catecholamine effects [8].

Antagonism of the GR by mifepristone (RU486), pharmacologically classified as both a progesterone and glucocorticoid antagonist [9], has been shown to ameliorate metabolic parameters in rodent model of type 2 diabetes (T2D) [10]. However, the potential for GR antagonists to exacerbate inflammation is a major concern limiting the use of GR antagonists for the treatment of diabetes, depression, and other conditions. It was postulated that RU486 could exacerbate the inflammatory response and lead to septic shock through inhibition of the body's mechanism for controlling inflammation by virtue of its ability to block the GR in phagocytes located at the site of invading bacteria [11], by disrupting the negative pituitary feedback, and by deteriorating adrenal cortex exhaustion [12]. In experimental animals, blockade of the GR by RU486 was shown to increase the mortality of endotoxemic rats administered lipopolysaccharide, and to increase TNF $\alpha$ production and toxicity [13]. There have also been reports of deaths from septic shock in patients using RU486 as an abortifacient [14-16].

The association between use of RU486 and deaths from septic shock has only been reported under the condition of abortion (via progesterone receptor antagonism). No causal relationship has been established between RU486 and septic shock. The use of RU486 in Cushing's syndrome [17-19], breast cancer [20], endometriosis [21], and leiomyoma [22] has not been associated with septic shock, although all the applications are also based on either progesterone receptor antagonism or GR antagonism. The incidence of septic shock may depend on disease conditions and RU486 dosages.

In the effort to develop GR antagonists for chronic treatment of diabetes, we desired to investigate the acute and chronic effect of GR antagonist on the inflammatory responses in animals under both normal and disease conditions at doses that are efficacious in the treatment of T2D. Therefore, the current study investigated the effect of acute and chronic use of RU486 on inflammatory cytokines in various mouse models, including normal AKR mice and two rodent models of T2D, the monogenic leptin receptor defect $\mathrm{db} / \mathrm{db}$ mice and the diet-induced obese (DIO) C57BL/6 mice.

\section{Results \\ RU486 dose-dependently decreased blood glucose but did not affect serum cytokines in $\mathrm{db} / \mathrm{db}$ mice}

At an age of 11-12 weeks, $\mathrm{db} / \mathrm{db}$ mice had significantly higher levels of blood glucose, HbA1c, serum insulin, total cholesterol, triglycerides, and interleukin-6 (IL-6), and similar level of serum monocyte chemoattractant protein-1 (MCP-1) compared with the C57BL/6J lean litter mates (Fig 1 and Table 1). Serum tumor necrosis factor alpha (TNF $\alpha)$ and interleukin-1beta (IL-1 $\beta$ ) were below quantifiable levels (BQL) in both $\mathrm{db} / \mathrm{db}$ mice and their lean litter mates. The $\mathrm{db} / \mathrm{db}$ mice also had significantly higher levels of serum corticosterone, similar levels of adrenocorticotropic hormone (ACTH), and higher expression levels of hepatic glucogenesis enzyme phosphenolpyruvate carboxykinase (PEPCK) and glucose-6phosphatase (G6Pase) genes compared with the C57BL/ 6J lean litter mates (Fig 1 and Table 1).

Treatment of the $\mathrm{db} / \mathrm{db}$ mice at an age 10-12 weeks with GR antagonist RU486 for 10 days significantly decreased postprandial blood glucose in a dose- and time-dependent manner (Fig 1a), confirming the glucose lowering effect of RU486 and establishing the efficacious dose. RU486 down-regulated hepatic PEPCK expression levels (Fig 1b), and trended to lower G6Pase (Fig 1c) gene expression, and increased serum levels of corticosterone (Fig 1e) and ACTH (Fig 1f) in db/db mice. RU486 did not affect serum MCP-1 and IL- 6 levels in the $\mathrm{db} / \mathrm{db}$ mice (Fig 1d).

\section{RU486 decreased LPS-induced serum TNF $\alpha$ in normal AKR mice along with an increase in serum corticosterone}

As shown in Fig 2, ninety minutes after LPS intraperitoneal (ip) injection, serum TNF $\alpha$ and IL-6 levels were increased in a dose- and time-dependent manner. The LPS doses of 0.1 and $0.5 \mathrm{mg} / \mathrm{kg}$ were the at the lower part of the dose-response curve for TNFa induction (Fig 2a), indicating that these doses should be far from the exhausting capacity for TNF $\alpha$ production. The 90 minute exposure time was also in the middle of TNFa release curve (Fig $2 \mathrm{~b})$. The LPS-induced IL-6 production, which was much more sensitive than $\mathrm{TNF} \alpha$ production, reached a maximal level at an LPS dose of $0.5 \mathrm{mg} / \mathrm{kg} 90$ minutes after exposure (Fig 2c and Fig 2d). In the subsequent studies of LPS challenge in AKR mice, the middle LPS doses of 0.1 and $0.5 \mathrm{mg} / \mathrm{kg}$, an exposure time of 90 minutes, and the parameter of TNF $\alpha$ production were employed.

While LPS doses of 0.1 and $0.5 \mathrm{mg} / \mathrm{kg}$ increased serum TNF $\alpha$ to different levels, oral RU486 significantly inhibited both LPS 0.1 and $0.5 \mathrm{mg} / \mathrm{kg}$-induced increase in serum TNF $\alpha$. This inhibition trended to be dose-dependent and is opposite to the proposed pro-inflammation effects of RU486 (Fig 3a and Fig 3d). Both LPS 0.1 and 0.5 

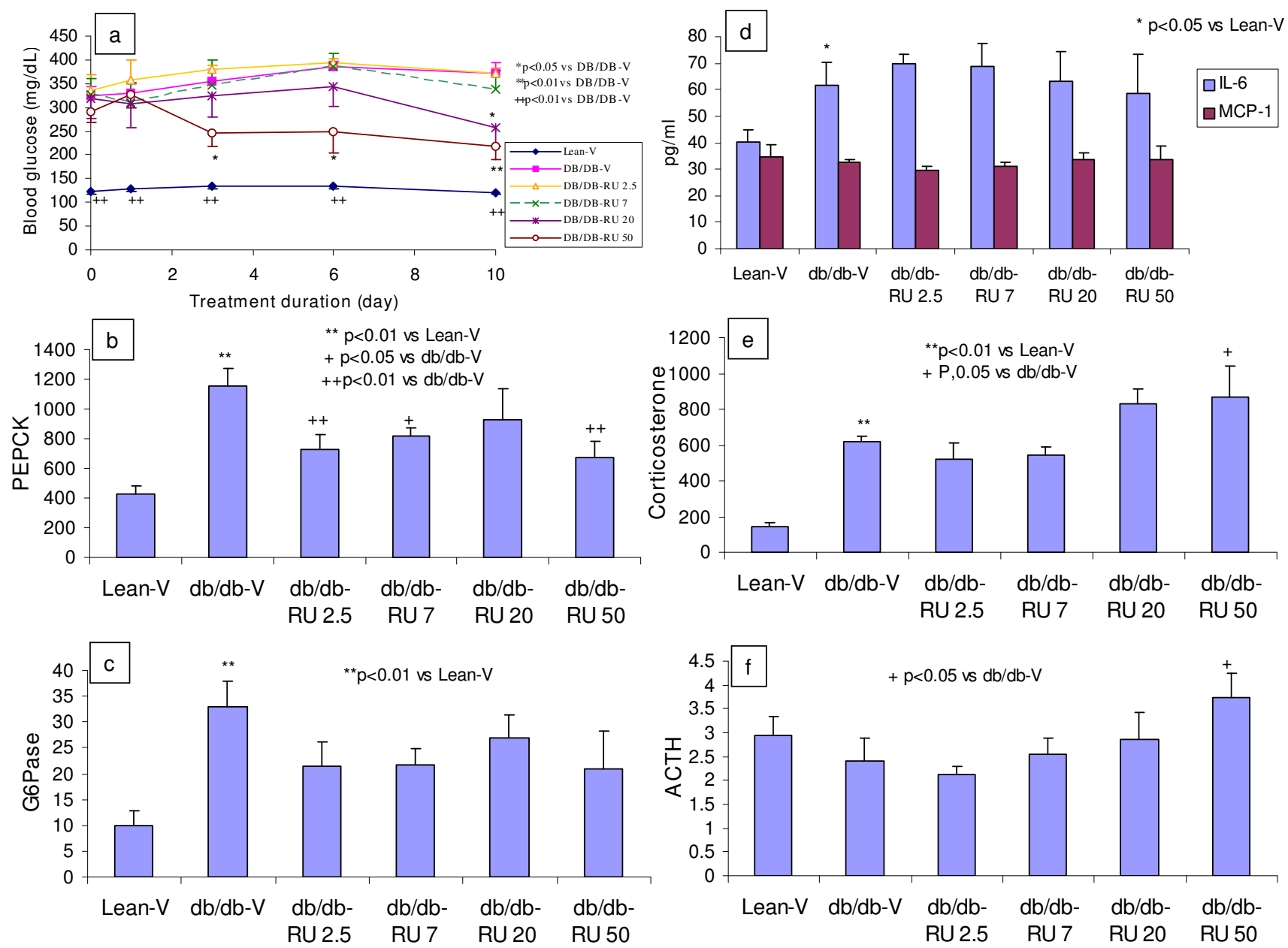

\section{Figure I}

Effects of RU486 (oral, BID, 10 days) on blood glucose (a), liver genes of PEPCK (b) and G6Pase (c), and serum IL-6 and MCP-I (d), corticosterone (e), and ACTH (f) in db/db mice. Lean-V: lean litter mates treated with vehicle. $\mathrm{db} / \mathrm{db}-\mathrm{V}: \mathrm{db} / \mathrm{db}$ mice treated with Vehicle. db/db-RU 2.5: db/db mice treated with RU486 $2.5 \mathrm{mg} / \mathrm{kg}$. $\mathrm{db} / \mathrm{db}-\mathrm{RU}$ 7: $\mathrm{db} / \mathrm{db}$ mice treated with RU486 $7 \mathrm{mg} / \mathrm{kg}$. db/db-RU 20: db/db mice treated with RU486 $20 \mathrm{mg} / \mathrm{kg}$. db/db-RU 50: db/db mice treated with RU486 $50 \mathrm{mg} / \mathrm{kg}$. Serum corticosterone and ACTH were presented as $\mathrm{ng} / \mathrm{ml}$. PEPCK and G6Pase were normalized with cyclophilin.

$\mathrm{mg} / \mathrm{kg}$ resulted in significantly higher serum corticosterone (Fig 3b and Fig 3e) and ACTH (Fig 3c and 3f). Pretreatment with RU486 further increased serum corticosterone in these animals, but did not affect the LPS-elevated ACTH (Fig 3c and Fig $3 f$ ).

\section{RU486 decreased low dose LPS-induced serum TNF $\alpha$ in C57BL/6 DIO mice along with an increase in serum corticosterone, but did not affect the high dose LPS- mediated changes}

After 12-13 weeks on cafeteria diet, C57BL/6 mice had a phenotype of higher body weight, serum glucose and insulin, dyslipidemia, and had higher serum TNFa and similar IL-6 (Table 2) compared to normal diet controls. Acute LPS challenge in C57BL/6 DIO mice markedly increased serum TNF $\alpha$ in a dose-dependent manner (Fig 4 ), which was more pronounced than that in normal diet controls (with LPS $20 \mathrm{mg} / \mathrm{kg}, 12852 \pm 1185 \mathrm{pg} / \mathrm{ml}$ vs $6494 \pm 1655 \mathrm{pg} / \mathrm{ml}$ in normal diet controls, $\mathrm{p}<0.05)$. Pretreatment with RU486 decreased the low dose $0.1 \mathrm{mg} / \mathrm{kg}$ LPS-induced serum TNF $\alpha$, but did not affect the higher dose $0.5 \mathrm{mg} / \mathrm{kg}$ LPS-elevated serum TNFa (Fig 4a). LPS increased serum corticosterone in the C57BL/6 DIO mice (Fig 4b). Pretreatment with RU486 further increased the LPS $(0.1$ and $0.5 \mathrm{mg} / \mathrm{kg})$-elevated serum corticosterone but did not affect serum ACTH (Fig 4b and 4c). 
Table I: Phenotype of db/db mice

\begin{tabular}{lcc}
\hline & Lean litter mates & $\mathrm{db} / \mathrm{db}$ mice \\
\hline Body weight $(\mathrm{g})$ & $24.1 \pm 0.6$ & $39.8 \pm 0.5^{* *}$ \\
Blood & $120.1 \pm 4.6$ & $319.9 \pm 37.5^{* *}$ \\
Glucose $(\mathrm{mg} / \mathrm{dL})$ & $3.2 \pm 0.2$ & $5.4 \pm 0.6^{* *}$ \\
HbAlc $(\%)$ & & \\
Serum & $0.3 \pm 0.1$ & $12.6 \pm 2.9^{* *}$ \\
Insulin $(\mathrm{ng} / \mathrm{ml})$ & $73.8 \pm 1.8$ & $127 \pm 3.2^{* *}$ \\
Total cholesterol $(\mathrm{mg} / \mathrm{dL})$ & $125.4 \pm 15.8$ & $200.9 \pm 19.5^{* *}$ \\
Triglycerides $(\mathrm{mg} / \mathrm{dL})$ & $40.1 \pm 4.5$ & $61.8 \pm 8.6^{*}$ \\
IL-6 $(\mathrm{pg} / \mathrm{ml})$ & $34.4 \pm 5.0$ & $32.4 \pm 1.0$ \\
MCP-I $(\mathrm{pg} / \mathrm{ml})$ & $\mathrm{BQL}$ & $\mathrm{BQL}$ \\
TNF $\alpha$ & $\mathrm{BQL}$ & $\mathrm{BQL}$ \\
IL-I $\beta$ & $45.7 \pm 17.8$ & $615 \pm 36.4^{* *}$ \\
Corticosterone $(\mathrm{ng} / \mathrm{ml})$ & $2.9 \pm 0.4$ & $2.4 \pm 0.5$ \\
ACTH $(\mathrm{ng} / \mathrm{ml})$ & & \\
\hline
\end{tabular}

$*_{p}<0.05$ vs lean litter mates. ${ }^{* *} p<0.01$ vs lean litter mates.

$B Q L:$ Below quantifiable level.

In another experiment, $\mathrm{C} 57 \mathrm{BL} / 6$ DIO mice were ip injected with LPS at the dose of $20 \mathrm{mg} / \mathrm{kg}$. This high dose of LPS led to inactivity and diarrhea in mice, an exaggerated increase in serum $\mathrm{TNF} \alpha$, and moderate increases in serum corticosterone and ACTH (Fig $4 \mathrm{~d}-\mathrm{f}$ ). Pretreatment with RU486 in the C57BL/6 DIO mice did not affect the high dose LPS-mediated changes in serum TNF $\alpha$, corticosterone, and ACTH (Fig 4d-f).
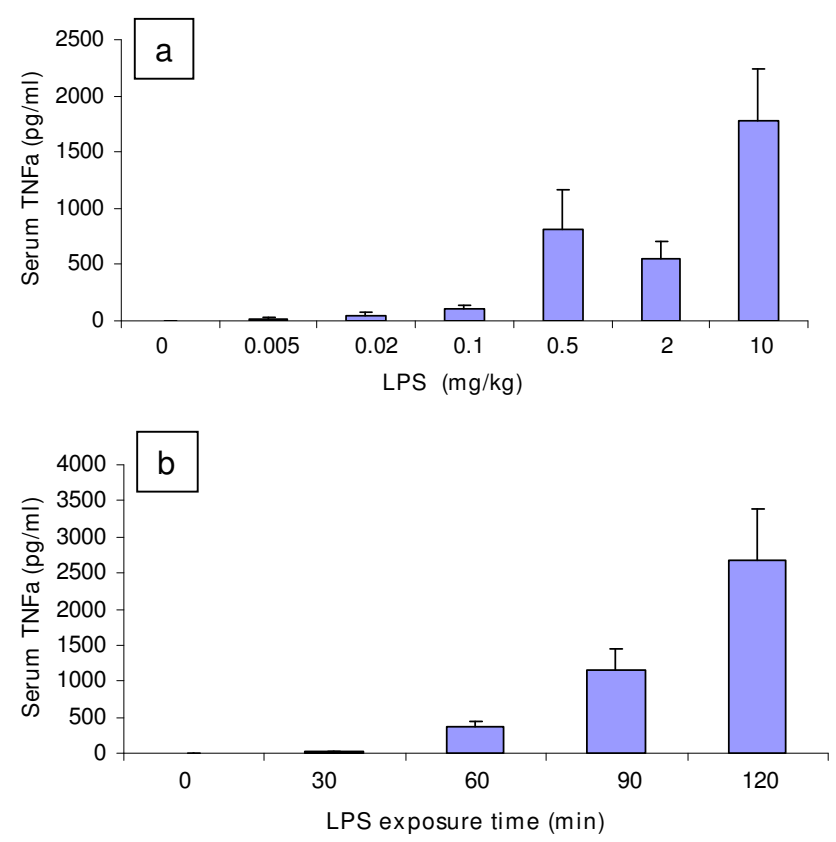

\section{Discussion}

The current study demonstrated that chronic treatment with GR antagonist RU486 for 10 days dose-dependently decreased postprandial blood glucose, increased serum corticosterone and ACTH, and did not affect serum MCP1 and IL- 6 , in $\mathrm{db} / \mathrm{db}$ mice. Injection of LPS increased circulating TNFa, corticosterone, and ACTH in both normal AKR mice and C57BL/6 DIO mice. RU486 suppressed the lower dose LPS-elevated serum TNF $\alpha$ in both normal AKR mice and C57BL/6 DIO mice, and further increased circulating corticosterone. The RU486 pretreatment did not affect the high dose LPS $(20 \mathrm{mg} / \mathrm{kg})$-mediated changes in serum TNF $\alpha$ and corticosterone. It is worth noting that the data sets from each strain/model examined were not exactly the same in current studies. But all the studies showed that RU486 either decreased cytokine along with increased corticosterone, or did not affect cytokine along with or without change in corticosterone. Thus RU486, at doses which are efficacious on glucose lowering, did not show any exacerbating effect on cytokine production in both chronic and acute settings, and RU486 could actually suppress the lower dose LPS-mediated TNF $\alpha$ release, possibly due to the increased release of GCs. The interpretation of the data sets were discussed below.

Although GR antagonism has been shown to inhibit gluconeogenesis and lower glucose in humans [1] and in rodent model of T2D [23], the concern about GR antago-
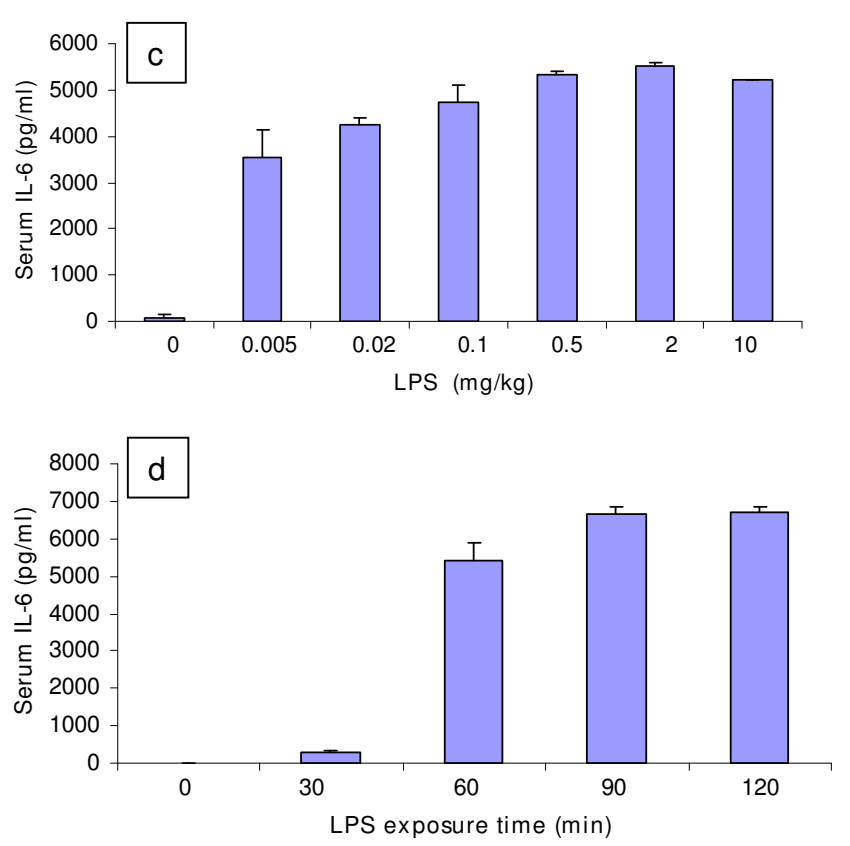

\section{Figure 2}

LPS induced dose-dependent TNF $\alpha$ (a) and IL-6 (c) production and LPS induced time-dependent TNF $\alpha$ (b) and IL-6 (d) production in AKR mice. LPS exposure time was 90 minutes in (a) and (c). LPS dose in (b) and (d) was $0.5 \mathrm{mg} /$ $\mathrm{kg}$. 

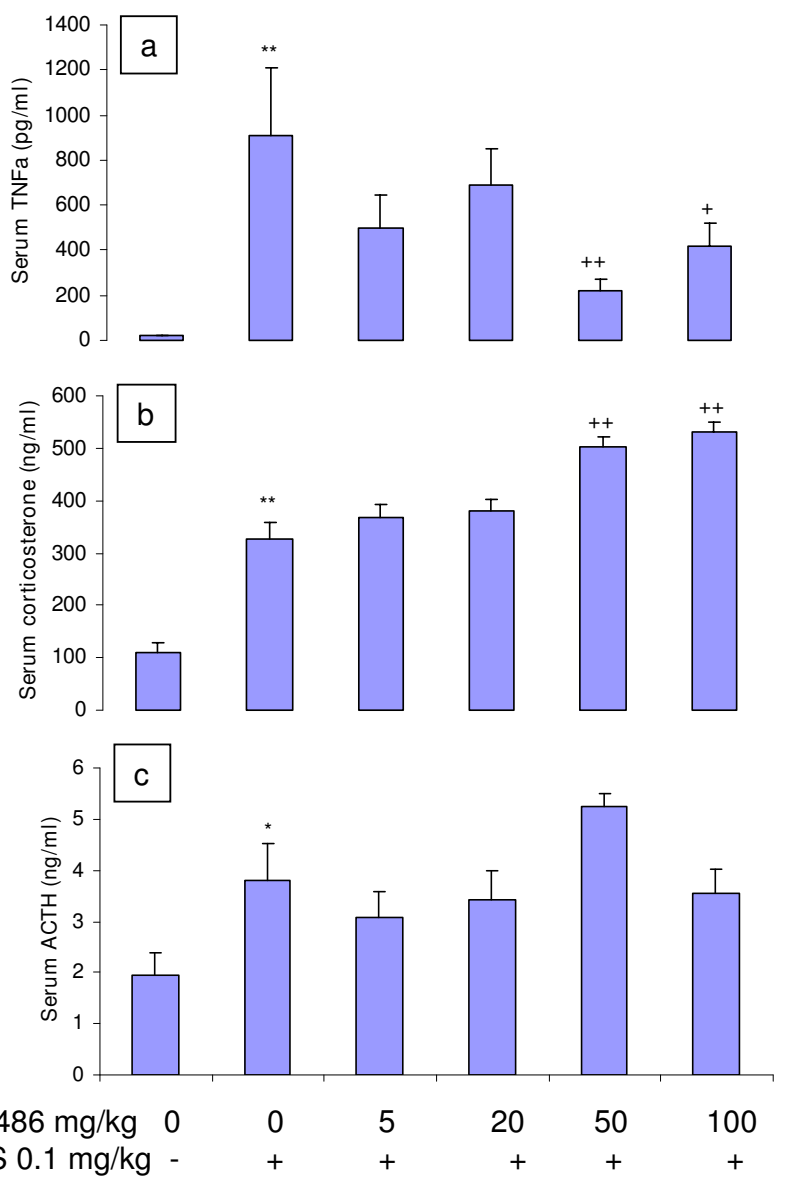
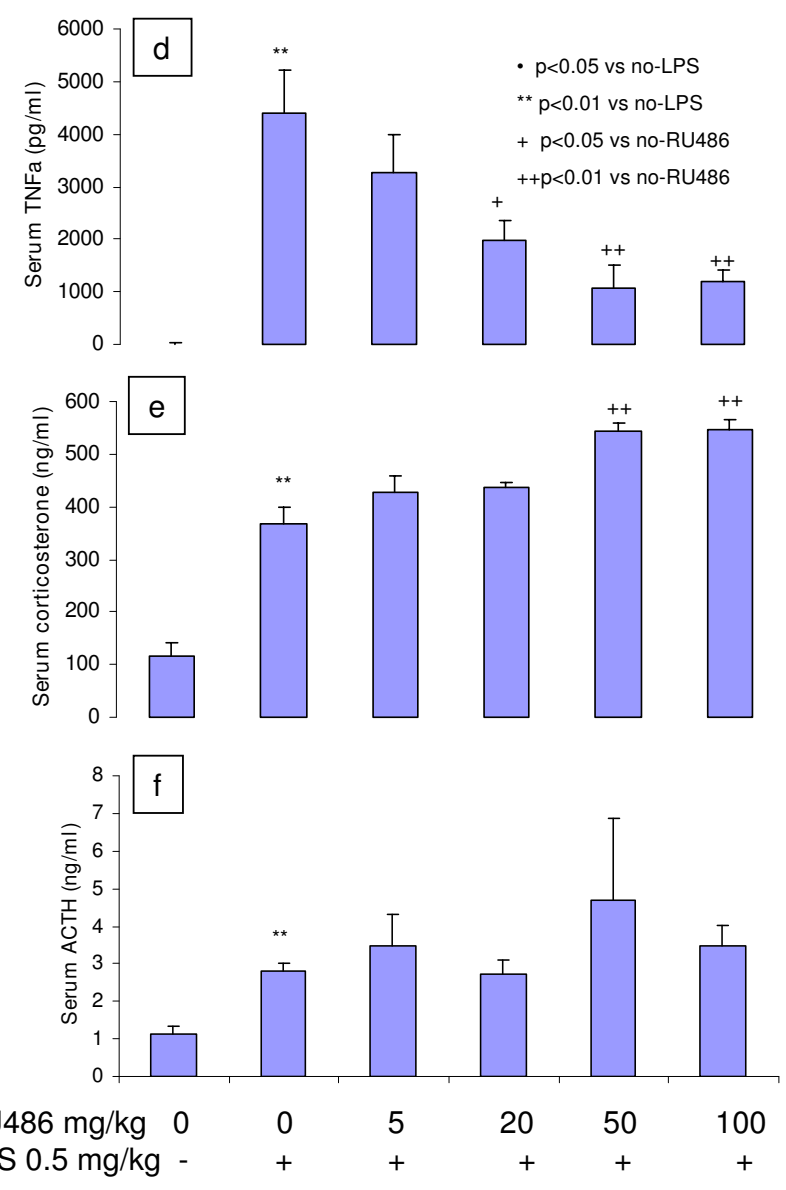

\section{Figure 3}

Effects of acute RU486 treatment on LPS (0.I and $0.5 \mathrm{mg} / \mathrm{kg})$-induced changes in serum TNF $\alpha$ (a and d), corticosterone (b and e), and ACTH (c and f) in normal AKR mice. RU486 was oral gavaged 30 minutes prior to ip LPS. LPS exposure time was 90 minutes.

nists on pro-inflammation hampers the long-term treatment with GR antagonists in T2D. The current study used $\mathrm{db} / \mathrm{db}$ mice to determine the effect of chronic RU486 on circulating cytokines, which is a simulative study to mimic drug use in patients with T2D. The authors found that RU486 dose-dependently decreased postprandial blood glucose, increased serum corticosterone and ACTH, but did not affect serum MCP-1 and IL-6, although the basal IL- 6 was higher in $\mathrm{db} / \mathrm{db}$ mice than in the lean littermate controls. The significantly higher level of IL- 6 in the $\mathrm{db} / \mathrm{db}$ mice is consistent with a state of chronic low-grade inflammation. The changes in glucose, corticosterone, and ACTH in RU486-treated db/db mice were consistent with relevant literature reports, and confirmed the efficacious drug exposure (measured serum drug level 2-3 hours after last dose: $14 \pm 3,33 \pm 3,273 \pm 17$, and $719 \pm$ $57 \mathrm{nM}$, respectively at doses of $2.5,7,20$, and $50 \mathrm{mg} / \mathrm{kg}$ ). These findings suggest that RU486 did not further enhance inflammation in this mouse model of T2D with low grade inflammation. The dose-effect curves of RU486 on glucose, corticosterone, and ACTH were used to decide the RU486 doses $4-100 \mathrm{mg} / \mathrm{kg}$ used in the subsequent acute studies.

In the treatment of septic shock, low doses of glucocorticoids have anti-inflammatory properties. GR antagonists might block the anti-inflammatory effect of endogenous cortisol, and deteriorate inflammation. Excessive LPS release from the bacterial wall into the circulation is the primary pathogenic process of septic shock [24]. To evaluate the effect of RU486 under the condition of septic shock, an LPS-challenge model was used in the current studies. We found that in normal AKR mice, LPS dosedependently increased serum TNF $\alpha$ and caused increases in corticosterone and ACTH. Since LPS-increased circulating TNF $\alpha$ and other circulating cytokines can trigger the 

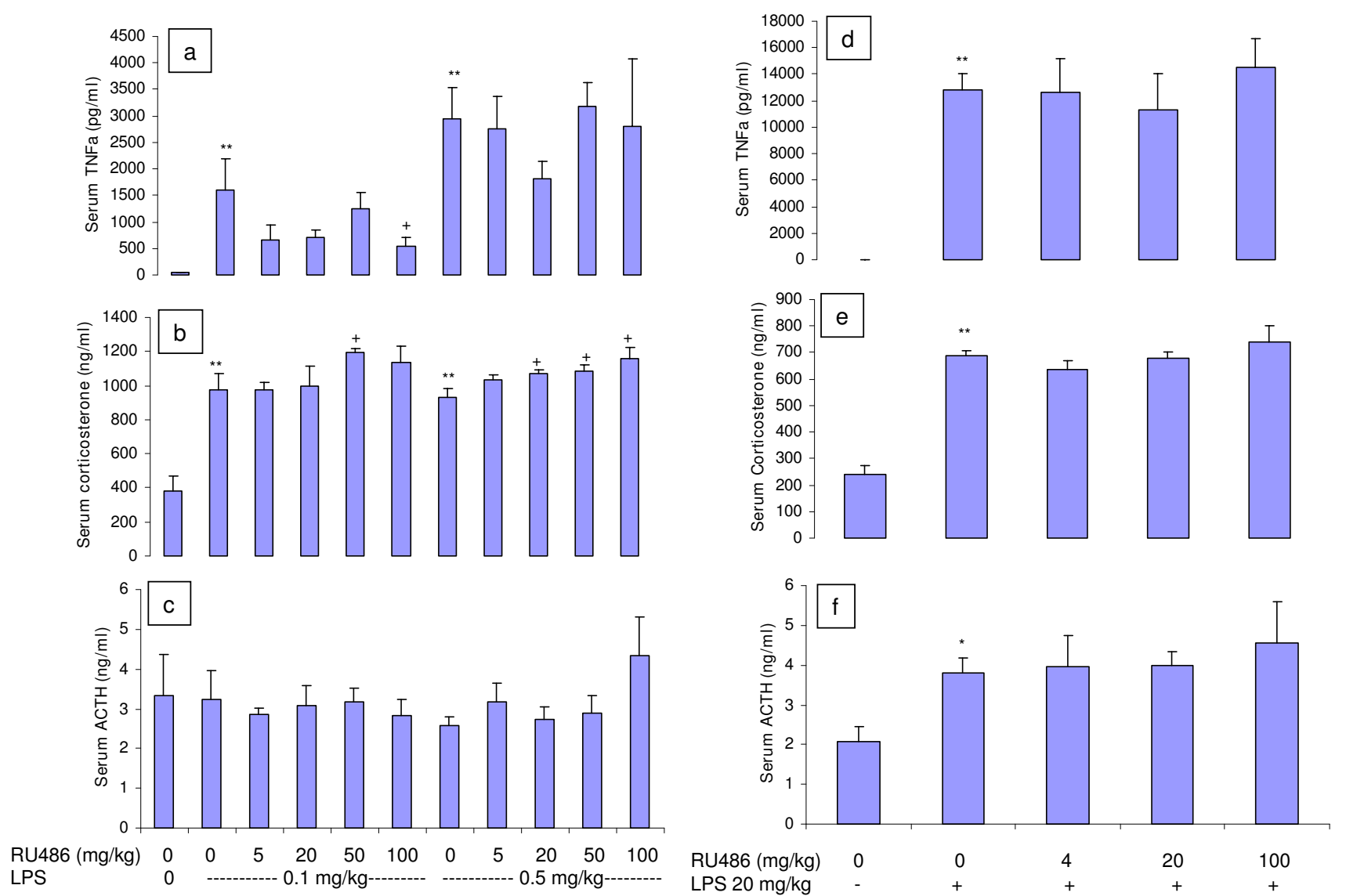

Figure 4

Effects of acute RU486 treatment on lower doses of LPS (0.I and $0.5 \mathrm{mg} / \mathrm{kg})$-induced changes in serum TNF $\alpha$ (a), corticosterone (b), and ACTH (c), and on high dose LPS (20 mg/kg)-induced changes in serum TNF $\alpha$ (d), corticosterone (e), and ACTH (f) in C57BL/6 DIO mice. RU486 was oral gavaged 30 minutes prior to ip LPS. LPS exposure time was 90 minutes. ${ }^{*} p<0.05$ vs no-LPS. ${ }^{* *} p<0.01$ vs no-LPS. $+p<0.05$ vs no-RU486.

Table 2: Phenotype of C57BL/6 DIO mice

\begin{tabular}{lcc}
\hline & Normal diet controls & DIO mice \\
\hline $\begin{array}{l}\text { Body weight }(\mathrm{g}) \\
\text { Blood }\end{array}$ & $28.7 \pm 0.3$ & $44.6 \pm 0.6^{* *}$ \\
Glucose (mg/dL) & $121 \pm 3$ & $160 \pm 6^{*}$ \\
HbAlc $(\%)$ & $3.6 \pm 0.2$ & $3.5 \pm 0.3$ \\
Serum & & \\
Glucose $(\mathrm{mg} / \mathrm{dL})$ & $225 \pm 15^{* *}$ & $344 \pm 22^{*}$ \\
Insulin $(\mathrm{ng} / \mathrm{ml})$ & $0.45 \pm 0.06$ & $5.07 \pm 1.03^{* *}$ \\
Total cholesterol (mg/dL) & $67.0 \pm 3.3$ & $223.0 \pm 3.1^{* *}$ \\
Triglycerides (mg/dL) & $93.0 \pm 14.6$ & $138.0 \pm 9.8^{*}$ \\
FFA (mEq/L) & $0.35 \pm 0.03$ & $0.47 \pm 0.02^{*}$ \\
IL-6 (pg/ml) & $191.2 \pm 86.7$ & $243.2 \pm 144.7$ \\
TNF $\alpha(\mathrm{pg} / \mathrm{ml})$ & $24.0 \pm 1.1$ & $35.6 \pm 2.4^{*}$ \\
Corticosterone $(\mathrm{ng} / \mathrm{ml})$ & $310 \pm 30$ & $380 \pm 86$ \\
ACTH $(\mathrm{ng} / \mathrm{ml})$ & $2.3 \pm 0.2$ & $3.3 \pm 1.0$ \\
\hline
\end{tabular}

$*_{p}<0.05$ vs lean litter mates. ${ }^{*} \mathrm{p}<0.01$ vs lean littermates. neural circuits that control the HPA axis [25], the increases in corticosterone and ACTH in response to LPS challenge were an expected stress response of HPA axis [26]. Interestingly, pretreatment with RU486 dose-dependently decreased serum $\mathrm{TNF} \alpha$, which is contrary to the hypothesis that RU486 would exacerbate inflammation. There was also a dose-dependent increase in circulating corticosterone in response to RU486 treatment, which is a well known compensatory reaction in response to the GR antagonism. Thus the suppression of LPS-mediated TNF $\alpha$ production in RU486-treated mice was most likely a consequence of the increased circulating corticosterone. Because of the compensatory increase in endogenous glucocorticoids, acute GR antagonism with RU486 does not necessarily lead to exacerbation of inflammation.

It has been reported that diet-induced obesity or/and dietinduced insulin resistance in mice is associated with low 
grade inflammation, as evidenced by macrophage accumulation in adipose tissue and increased serum cytokines $[27,28]$. Chronic low-grade inflammation in these mice could alter the effects of RU486 on LPS-induced TNF $\alpha$ production compared to the effects in normal mice. Therefore, we used C57BL/6 DIO mice to determine the effects of LPS and RU486. The phenotype of the C57BL/6 DIO mice was consistent with the literature [29]. While the LPS-induced increases in serum TNFa and corticostrone were similar to those in normal AKR mice, the effects of RU486 pretreatment on the LPS-mediated changes in C57BL/6 DIO mice were different than that in the normal AKR mice. RU486 suppressed $0.1 \mathrm{mg} / \mathrm{kg}$ LPSinduced TNF $\alpha$ production but did not affect $0.5 \mathrm{mg} / \mathrm{kg}$ LPS-induced TNF $\alpha$ production, despite the fact that RU486 further increased serum corticosterone at both LPS doses. Thus, under these conditions, the compensatory increase in glucocorticoids was not able to suppress LPSinduced TNF $\alpha$ production.

Considering that the stress response during sepsis could exhaust adrenal cortex, a very high dose of exogenous LPS could mimic this state and would exhaust the endogenous glucocorticoids. Under these conditions, RU486 may no longer be able to cause compensatory glucocorticoid release. Whether RU486 pretreatment exacerbates LPSinduced TNF $\alpha$ production under this condition is not known. Therefore, we used LPS $20 \mathrm{mg} / \mathrm{kg}$ in C57BL/ 6 DIO mice to observe the effect of RU486 in this stressed condition. We found that this very high dose of LPS led to an exaggerated increase in serum $\mathrm{TNF} \alpha$, but increases in serum corticosterone and ACTH were similar to those observed after LPS 0.1 and $0.5 \mathrm{mg} / \mathrm{kg}$. RU486 pretreatment did not affect the $20 \mathrm{mg} / \mathrm{kg}$ LPS-mediated changes in TNF $\alpha$, corticosterone, and ACTH. Despite this lack of increase in glucocorticoids, RU486 did not enhance TNF $\alpha$ production.

There are a few papers reporting GR agonist activity of RU486 in some in vitro and in vivo systems. Nordeen et al [30] reported that protein kinase A activators unmasked the agonist effect of RU486 as mediating an induction of hormone-responsive report genes. Zhang et al [31] reported that the GR agonist activities of RU486 were dependent on the GR levels but not on EC50 values in COS-7 cells transfected with GR expression vector. Schulz et al [32] reported that the RU486-induced GR agonism was controlled by the receptor $\mathrm{N}$ terminus and by corepressor binding. All these reports indicated that RU486 may act as a GR agonist under certain conditions on certain pathways/procedures. This agonist activity of RU486 may contribute to our observation of decreasing LPSinduced TNF $\alpha$ by RU486 in normal AKR mice and C57Bl/ 6 DIO mice. Although the mechanism and extent of GR agonist activities of RU486 in whole animals is not known, the GR agonist activities of RU486 reduce the extent of, and concerns about, potential inflammatory exacerbation by the drug.

As demonstrated in the current studies, LPS challenge is a strong stress to the subjects. LPS not only increases cytokine production (such as TNF $\alpha$ and IL-6), but also stimulates HPA axis and leads to increases in both serum corticosterone and ACTH. The levels of cytokine, ACTH, and corticosterone are considered to be the homeostatic status under the LPS-challenge. In the HPA axis, GCs have negative feedback effects on hypothalamus and anterior pituitary gland. GR antagonism with RU486 blocks the GR throughout body tissues and even blocks GCs' negative feedback receptors in the hypothalamus and anterior pituitary gland. This blockade leads to activation of HPA, and results in increased rate of synthesis and release of ACTH and GCs. The current studies in AKR mice and C57BL/6 DIO mice demonstrated that the acute RU486 pretreatment resulted in an increase only in corticosterone but not in ACTH. This finding indicates that GCs may have a negative feedback on the adrenal cortex, thus regulating its own synthesis and release.

Although the 5 deaths of septic shock were reported to be associated with use of RU486 [14-16], and antagonism of the GR was hypothesized to be the primary cause [16], the current studies in three different strains of animals with normal and abnormal metabolism have not shown inflammatory exacerbation by RU486 treatment. This suggests, notwithstanding the species and strain differences, that mechanisms other than, or along with, antagonism of the GR may contribute to the inflammatory exacerbation exhibited by RU486 in obstetric/gynecologic clinic. RU486 also blocks progesterone receptors [33], and progesterone also demonstrates anti-inflammatory properties [34-37]. Therefore, the septic shock associated with use of RU486 as abortifacient may not be solely due to antagonism of the GR by RU486. The exact cause of these deaths needs to be further investigated.

\section{Conclusion}

Our studies demonstrated that chronic treatment with GR antagonist RU486 in $\mathrm{db} / \mathrm{db}$ mice and acute use of RU486 in LPS-challenged normal and DIO mice did not show any evidence of exacerbating cytokine production. These findings suggest that the compensatory increase in circulating GCs induced by RU486 treatment results in an net anti-inflammatory effect, and suggest that the septic shock associated with use of RU486 as an abortifacient is not solely due to GR antagonism. 


\section{Methods \\ Experimental animals}

All procedures performed were in compliance with the Animal Welfare Act and U.S. Department of Agriculture regulations, and were approved by the GlaxoSmithKline Animal Care and Use Committee. Male AKR mice (8-9 weeks old) were purchased from Jackson Laboratory (Bar Harbor, ME) and were fed rodent chow Purina 5001 (PMI Nutrition International, LLC, Brentwood, Mo). Db/db mice (8-9 weeks old) and C57BL/6J lean litter mates (for $\mathrm{db} / \mathrm{db}$ control, 8-9 weeks old) were purchased from Jackson Laboratory (Bar Harbor, ME) and were fed PMI 5K67 diet (PMI Nutrition International, LLC, Brentwood, Mo). Male C57BL/6 mice (5-6 weeks) were purchased from Taconic (Hudson, NY) and were fed cafeteria diet (rodent chow Purina 5001, Lard diet with 60\% fat source calorie, and condensed milk diet, Research Diets, Inc., New Brunswick, NJ) for 12-13 weeks (preparing the diet-induced obesity mice, i.e., DIO mice), or fed rodent chow Purina 5001 for normal diet controls. Animals ate and drank ad libitum. AKR mice and $\mathrm{db} / \mathrm{db}$ mice were acclimatized for 1 week before experimental procedures.

\section{RU486 in db/db mice}

$\mathrm{Db} / \mathrm{db}$ mice were monogenic leptin receptor defect mice, with a phenotype of T2D. This strain of mice was used to simulate the effect of RU486 on T2D subjects.

Six groups of mice ( $n=5 \sim 9 /$ each group) were assigned as follows: $\mathrm{db} / \mathrm{db}$ mice treated with RU486 0 (vehicle), 2.5, 7,20 , and $50 \mathrm{mg} / \mathrm{kg}$, BID, PO, and C57BL/6J lean litter mates treated with vehicle $0.5 \%$ hydroxypropyl methylcellulose- $0.1 \%$ tween $8010 \mathrm{ml} / \mathrm{kg}$, BID, PO, for 10.5 days. Postprandial blood glucose was monitored before starting treatment and 1, 3, 6, and 10 days after treatment between 7-8 am prior to morning dosing, via tail snip (3-4 $\mathrm{mm}$ from the tip) using Elite ${ }^{\circledast}$ XL Glucometer (Bayer, Tarrytown, NY). 2-3 hours after the last dose, mice were anesthetized under isoflurane. Blood was collected via cardiac stick for measuring HBA1c and obtaining serum. Liver samples were collected for determining gene expression levels of glucogenesis enzyme PEPCK and G6Pase. Serum was used for measuring inflammatory parameters TNF $\alpha$, MCP-1, IL-1 $\beta$, andIL-6; HPA axis parameters ACTH, and corticosterone; and metabolic parameters glucose, insulin, total cholesterol, and triglycerides.

\section{RU486 in AKR mice acutely challenged with lipopolysaccharide (LPS)}

AKR mice, at age 9-10 weeks old and fed ordinary rodent diet, were normal in metabolism [38]. This strain of mice was used to simulate the effect of RU486 on LPS-induced cytokine release in healthy subjects.
To demonstrate the effect of LPS on serum cytokine production, one set of AKR mice was intraperitoneally (ip) injected with LPS $0.001-10 \mathrm{mg} / \mathrm{kg}$ (in saline), then subjected to blood collection via cardiac stick under isoflurane 90 minutes after LPS injection; another set of AKR mice was ip injected with LPS $0.5 \mathrm{mg} / \mathrm{kg}$, then subjected to blood collection via cardiac stick under isoflurane 30 , 60, 90, and 120 minutes after LPS injection. Serum separated from the blood samples was analyzed for TNF $\alpha$, IL6 , corticosterone, and ACTH. To determine the effect of RU486 on LPS-stimulated cytokine production in vivo, AKR mice were orally gavaged with vehicle or RU4865, 20,50 , or $100 \mathrm{mg} / \mathrm{kg}$. Thirty minutes later, the mice were ip injected with LPS 0.1 or $0.5 \mathrm{mg} / \mathrm{kg}$. Blood samples were collected via cardiac stick under isoflurane 90 minutes after LPS injection. Serum separated from the blood samples was analyzed for TNF $\alpha$, corticosterone, and ACTH.

\section{RU486 in C57BL/6 DIO mice acutely challenged with lipopolysaccharide (LPS)}

C57BL/6 DIO mice were mice with abnormal metabolism resulted from over eating and high fat diet. This strain of mice was used to simulate the effect of RU486 on LPSinduced cytokine release in T2D subjects.

To determine the effect of RU486 on LPS-stimulated cytokine production in animals with metabolic disorders, one set of C57BL/ 6 DIO mice was orally treated with vehicle or RU486 4, 20, $100 \mathrm{mg} / \mathrm{kg}$. Thirty minutes later, the mice were ip injected with LPS $0.1,0.5$ or $20 \mathrm{mg} / \mathrm{kg}$. Blood samples were collected via cardiac stick under isoflurane 90 minutes after LPS injection. Serum separated from the blood samples was analyzed for $\mathrm{TNF}$, corticosterone, and ACTH.

\section{Bioassays}

Serum TNF- $\alpha$ and IL- 6 were measured using ELISA kits (cat. \# EMTNFA5 and EM2IL65 respectively) from Pierce Biotechnology, Inc. (Rockford, IL). Serum MCP-1 and IL$1 \beta$ were measured using a customized MSD kit of Meso Scale Diagnostic, LLC (Gaithersburg, MD). Serum corticosterone was measured using an ELISA kit OCTEIA Corticosterone (Ref. AC-14F1) of IDS Inc. (Fountain Hills, AZ). Serum ACTH was measured using an ELISA kit ACTH 1-39 (cat. \# S-1130) of Peninsula Laboratories, Inc (San Carols, CA). Serum glucose, total cholesterol, and triglycerides were measured with the Olympus Au640 ${ }^{\circledast}$ clinical chemistry analyzer (Serial \#2040881, Olympus America Inc, Diagnostic Systems Group, Two Corporate Center Drive, Melville, NY). Blood HBA1c was measured with the Bio-Rad Variant II Hemoglobin Analysis System (Bio-Rad Diagnostics, Hercules California) utilizing the principles of boronate affinity HPLC. 
Determination of PEPCK and G6Pase gene expression in liver of $\mathrm{db} / \mathrm{db}$ mice by real time $P C R$

Total RNA in mouse liver was isolated by the TRIZOL ${ }^{\circledR}$ method [39]. All RNA samples were DNased using the DNA-free $^{\mathrm{TM}}$ kit (Ambion, Austin, TX) according to the manufacturer's protocol. The samples were then converted to cDNA using the High Capacity cDNA Archive Kit (Applied Biosystems, Foster City, CA) according to protocol. PCR results were generated using the 5 ' nuclease assay (TaqMan) [40] and the ABI 7900 Sequence Detection System (Applied Biosystems, Foster City, CA). Primers and probe for PEPCK are: Forward-TTGAACCTGAAAGGCCTGGG; Reverse-AAGGGAGGTCGGTGTTGACC; ProbeCGTCAACGTGGAGGAGCTGTTTGGGAT. Primers and probe for G6Pase are: Forward-CTGCATTGTGGCTTCCTTGG; Reverse-ATGCAAAGGGAACTGTTGCG; ProbeGCCCCCATCCCAGGTTGAGTTGATCTT. The primers and probe for Cyclophilin are: Forward-GGCCGATGACGAGCCC; Reverse-TGTCTTTGGAACTTTGTCTGCAA; Probe-TGGGCCGCGTCTCCTTCGA. The PCR cycling conditions were $95^{\circ} \mathrm{C}$ for 10 minutes, and 40 cycles of $95^{\circ} \mathrm{C}$ for 15 seconds and $60^{\circ} \mathrm{C}$ for 1 minute.

\section{Reagents}

RU486 (Mifepristone, Cat. \# M8046) and lipopolysaccharides (LPS, Cat. \# L3755, Batch \# 046K4068) were purchased from Sigma-Aldrich (St. Louis, MO).

\section{Statistical analysis}

There were 5-9 mice for each data point. Data are presented as mean \pm SEM. Differences between each pair of groups were analyzed with Student's t-test using JMP 6.0.0 software. A P value less than 0.05 was taken to be significant.

\section{Competing interests}

The authors declare that they have no competing interests.

\section{Authors' contributions}

BY is the principal investigator. YS, JAMcN, LGC, and PL participated in the experiments. PL, RPT, SAS, and GLP participated in the study design and manuscript preparation.

\section{Acknowledgements}

The authors thank Jeff Cobb and lain J Uings for their substantial contributions to the conception.

\section{References}

I. Garrel DR, Moussali R, De Oliveira A, Lesiege D, Lariviere F: RU 486 prevents the acute effects of cortisol on glucose and leucine metabolism. J Clin Endocrinol Metab 1995, 80:379-385.

2. Jacobson PB, von Geldem TW, Ohman L, Osterland M, Wang J, Zinker B, et al.: Hepatic glucocorticoid receptor antagonism is sufficient to reduce elevated hepatic glucose output and improve glucose control in animal models of type 2 diabetes. J Pharm Exper Thera 2005, 3 I 4:191-200.
3. Holsboer F: Therapeutics for depression and anxiety disorders. Drug Discovery Today: Therapeutic Strategies 2004, I: I05-109.

4. Miech RP: Pathophysiology of mifepristone-induced septic shock due to Clostridium Sordellii. Ann Pharmacother 2005 , 39:|483-1488.

5. Annane D, Cavaillon J: Corticosteroids in sepsis: from bench to bedside? Shock 2003, 20:197-207.

6. Webster JI, Sternberg EM: Role of the hypothalamic-pituitaryadrenal axis, glucocorticoids and glucocorticoid receptors in toxic sequelae of exposure to bacterial and viral products. Journal of Endocrinology 2004, 181:207-221.

7. Gaillard RC: Interaction between the hypothalamo-pituitaryadrenal axis and the immunological system. Ann Endocrinol (Paris) 2001, 62(2): 155-163.

8. Williamson DR, Lapointe M: The hypothalamic-pituitary-adrenal axis and low-dose glucocorticoids in the treatment of septic shock. Pharmacotherapy 2003, 23:5।4-525.

9. Leonhardt A, Boonyaratanakornkit V, Edwards DP: Progesterone receptor transcription signaling mechanisms. Steroids 2003, 68:761-770.

10. Gettys TW, Watson PM, Taylor IL, Collins S: RU-486 (Mifepristone) ameliorates diabetes but does not correct deficient beta-adrenergic signaling in adipocytes from mature C57BL/ 6J-ob/ob mice. Int J Obes Relat Metab Disord 1997, 2 I :865-873.

II. Hawes AS, Rock CS, Keogh CV, Lowry SF, Calvano SE: In vivo effects of the antiglucocorticoid RU486 on glucocorticoid and cytokine responses to Escherichia Coli endoxin. Infect Immun 1992, 60:264I-2647.

12. Gaillard RC, Riondel A, Muller AF, Herrmann W, Baulieu EE: RU486: a steroid with antiglucocorticoid activity that only disinhibits the human pituitary-adrenal system at a specific time of day. Proc Natl Acad Sci USA 2006, 8 I:3879-3882.

13. Lazar G Jr, Duda E, Lazar G: Effect of RU 38486 on TNF production and toxicity. FEBS letters |992, 308:|37-|40.

14. Danco Laboratories: Danco Laboratories announced today that it is modifying the labeling for Mifeprex to include updated safety information. . 7-18-2005

15. FDA Public Health Advisory: Sepsis and Medical Abortion. 2005.

16. Sinave C, LeTemplier G, Blouin D, Leveilli F, Deland E: Toxic shock syndrome due to Clostridium sordellii: a dramatic postpartum and postabortion disease. Clin Infect Dis 2002, 35: |44|-1443.

17. Morris M, Grossman A: The Medical Management of Cushing's Syndrome. Ann New York Acad Sci 2002, 970: I I9-I33.

18. Nieman LK, Chrousos GP, Kellner C, Spitz IM, Nisula BC, Cutler GB et al:: Successful treatment of Cushing's syndrome with the glucocorticoid antagonist RU 486. J Clin Endocrinol Metab 1985, 61:536-540.

19. Sartor O, Cutler GB Jr: Mifepristone: Treatment of Cushing's Syndrome [New Applications of Mifepristone (RU 486)]. Clinical Obstetrics and Gynecology 1996, 39:506-510.

20. Spitz IM, Bardin CW: Mifepristone (RU 486) - A Modulator of Progestin and Glucocorticoid Action. New Engl J Med 1993, 329:404-4I2.

21. Kettel LM, Murphy AA, Morales AJ, Ulmann A, Baulieu EE, Yen SS: Treatment of endometriosis with the antiprogesterone mifepristone (RU486). Fertil Steril 1996, 66:669-670.

22. University of Rochester Medical Center: Rochester Study Rolls Out RU-486 To Treat Uterine Fibroids. 2006.

23. Link JT, Sorensen B, Patel J, Grynfarb M, Goos-Nilsson A, Wang J, et al.: Antidiabetic Activity of Passive Nonsteroidal Glucocorticoid Receptor Modulators. J Med Chem 2005, 48:5295-5304.

24. Lamping N, Dettmer R, Schröder NWJ, Pfeil D, Hallatschek W, Burger R, et al.: LPS-binding Protein Protects Mice from Septic Shock Caused by LPS or Gram-negative Bacteria. J Clin Invest 1998, I0 I:2065-207I.

25. Rivest S: How circulating cytokines trigger the neural circuits that control the hypothalamic-pituitary-adrenal axis. Psychoneuroendocrinology 2001, 26:761-788.

26. Marx C: The systemic adrenal stress response in severe sepsis and critical illness. Clin Intensive Care 2005, 16:57-64.

27. Xu H, Barnes GT, Yang Q, Tan G, Yang D, Chou CJ, et al.: Chronic inflammation in fat plays a crucial role in the development of obesity-related insulin resistance. J Clin Invest 2003, I | 2: 1821-1830. 
28. Wellen KE, Hotamisligil GS: Inflammation, stress, and diabetes. J Clin Invest 2005, I I 5: I I I I- I I I9.

29. Ahrén B, Simonsson E, Scheurink AJ, Mulder H, Myrsén U, Sundler F: Dissociated insulinotropic sensitivity to glucose and carbachol in high-fat diet-induced insulin resistance in C57BL/6] mice. Metabolism 1997, 46:97-106.

30. Nordeen SK, Bona BJ, Moyer ML: Latent agonist activity of the steroid antagonist, RU486, is unmasked in cells treated with activators of protein kinase A. Mol Endocrin 1993, 7:731-742.

31. Zhang S, Jonklaas J, Danielsen M: The glucocorticoid agonist activities of mifepristone (RU486) and progesterone are dependent on glucocorticoid receptor levels but not on EC50 values. Steroids 2007, 72:600-608.

32. Schulz M, Eggert M, Baniahmad A, Dostert A, Heinzel T, Renkawitz R: RU486-induced glucocorticoid receptor agonism is controlled by the receptor $\mathbf{N}$ terminus and by corepressor binding. J Biol Chem 2002, 277:26238-26243.

33. Donaldson MS, Dorflinger L, Brown SS, Benet LZ: Clinical Applications of Mifepristone (RU486) and Other Antiprogestins. Washington DC: National Academies Press; 1993.

34. Davies D, Dai D, Wolf DM, Leslie KK: Immunomodulatory and transcriptional effects of progesterone through progesterone $A$ and $B$ receptors in $H$ ec50co poorly differentiated endometrial cancer cells. J Society Gyn Invest 2004, I I:494-499.

35. Davies S, Dai D, Feldman I, Pickett G, Leslie KK: Identification of a novel mechanism of NF-kappaB inactivation by progesterone through progesterone receptors in $\mathrm{Hec} 50$ co poorly differentiated endometrial cancer cells: induction of A20 and ABIN-2. Gynecol Oncol 2004, 94:463-470.

36. Elovitz M, Wang Z: Medroxyprogesterone acetate, but not progesterone, protects against inflammation-induced parturition and intrauterine fetal demise. Am J Ob Gyn 2004, 190:693-70I.

37. Tibbetts TA, Conneely OM, O'Malley BW: Progesterone via its receptor antagonizes the pro-inflammatory activity of estrogen in the mouse uterus. Biol Reproduction 1999, 60: I I58-1 I65.

38. Strain Name: AKR/] [http://jaxmice.jax.org/strain/000648.html]

39. Chirgwin JM, Przybyla AE, MacDonald RJ, Rutter WJ: Isolation of biologically active ribonucleic acid from sources enriched in ribonuclease. Biochemistry 1979, I 8:5294-5299.

40. Bustin S: Absolute quantification of mRNA using real-time reverse transcription polymerase chain reaction assays. J Mol Endocrinol 2000, 25:169-193.

\section{Publish with Bio Med Central and every scientist can read your work free of charge}

"BioMed Central will be the most significant development for disseminating the results of biomedical research in our lifetime. "

Sir Paul Nurse, Cancer Research UK

Your research papers will be:

- available free of charge to the entire biomedical community

- peer reviewed and published immediately upon acceptance

- cited in PubMed and archived on PubMed Central

- yours - you keep the copyright
BioMedcentral 